\title{
Does Attenuated Mckittrick-Wheelock Syndrome Exists?
}

\author{
Hafif Mckittrick-Wheelock Sendromu Var Olabilir mi?
}

\author{
(1) Sadettin Er, (1) Bülent Cavit Yüksel, (1) Sabri Özden, (1) Deniz Tikici, (1) Barış Doğu Yıldız, (1) Mesut Tez \\ University of Health Sciences, Ankara Numune Training and Research Hospital, Clinic of General Surgery, Ankara, Turkey
}

\begin{abstract}
McKittrick-Wheelock syndrome is caused by fluid and electrolyte hypersecretion from colorectal tumor. We present a patient with large villous adenoma who had hyponatremia and rectal bleeding and treated with laparoscopic surgery. A 52-year-old female patient presented with rectal bleeding and hyponatremia (117 mEq/lt sodium) in biochemistry. After electrolytic replacement therapy and preoperative colonoscopy and magnetic resonance imaging examinations, the patient underwent laparoscopic surgery and full postoperative recovery was achieved. This case raises the question whether there are mild forms of McKittrick-Wheelock syndrome.
\end{abstract}

Keywords: Villous adenoma, hyponatremia, McKittrickWheelock syndrome

\section{öZ}

McKittrick-Wheelock sendromu kolorektal bir tümörün yüksek miktarda sıvı ve elektrolit salgılamasıyla oluşur. Bu yazıda büyük bir villöz adenom nedeniyle hiponatremi ve rektal kanaması olan ve laparoskopik cerrahi ile tedavi edilen bir hastayı bildirmekteyiz. Elli iki yașında kadın hasta rektal kanama ve hiponatremi (117 mEq/lt) ile başvurdu. Elektrolit replasman tedavisi ile preoperatif kolonoskopi ve manyetik rezonans görüntüleme ardından hastaya laparoskopik cerrahi uygulandı ve postoperatif tam iyileşme sağlandı. Bu olgu McKittrick-Wheelock sendromunun daha hafif formlarının olabileceği sorusunu akla getirmektedir.

Anahtar Kelimeler: Villöz adenom, hiponatremi, McKittrickWheelock sendromu

\section{Introduction}

Villous adenomas of colon might cause electrolyte and protein loss. This phenomenon was first described by McKittrick and Wheelock in 1954 (1) and then by Mckittrick et al. (2) in 1956. McKittrick and Wheelock syndrome is a complex clinical syndrome including fluid and electrolyte imbalance, hypovolemic shock and renal dysfunction due to colonic villous adenoma. Symptoms and findings of this syndrome are hyponatremia (headache, muscle cramps, lethargy etc.) and hypokalemia (paresthesia, ileus, hypotension, arrhythmia etc.) $(3,4)$.

\section{Case Report}

Sixty-seven years old female patient was evaluated in our outpatient clinic for rectal bleeding and a mass was palpated in rectal examination. A detailed colonoscopy revealed a 6-7 cm villous adenoma occupying the rectal lumen at $8 \mathrm{~cm}$ from anal verge. The biopsy of the mass showed severe dysplasia. A computed tomography of the abdomen showed multilobular mass inside rectum (Figure 1). The patient was hospitalized for surgery, but her serum sodium level was $117 \mathrm{mEq} / \mathrm{lt}$. Multidisciplinary intervention was undertaken to normalize intractable low serum sodium levels that could only be raised to $130 \mathrm{mEq} / \mathrm{lt}$. The surgery was delayed for one week. Later, the patient had a laparoscopic low anterior resection. Serum sodium level on postoperative day 1 was $138 \mathrm{mEq} / \mathrm{lt}$ and it remained stable thereafter. Pathological examination of the resected mass revealed villous adenoma without any findings of malignancy. Written informed consent was obtained from the patient.

\section{Discussion}

Three percent of villous adenomas, particularly those larger than 7-18 $\mathrm{cm}$, have secretory activity (5). These adenomas are mainly localized in the rectum, but also rarely in sigmoid colon (5-7). Not all of these adenomas present with Mckittrick-Wheelock syndrome (MWS), which has rather severe clinical symptoms. This was also true for our patient who only had intractable hyponatremia. In the context of complexity of MWS, single electrolyte deficiency of our case raises the question whether this is an attenuated form of the syndrome. In a case series involving 35 patients with MWS, hyponatremia is the second most common finding after hypokalemia and renal failure. These metabolic disarrangements in surgical patients adversely affect management of patients.

Villous adenoma and electrolyte disorders are also seen in CronkhiteCanada syndrome, thalassemia, cirrhosis, deep venous thrombosis, 


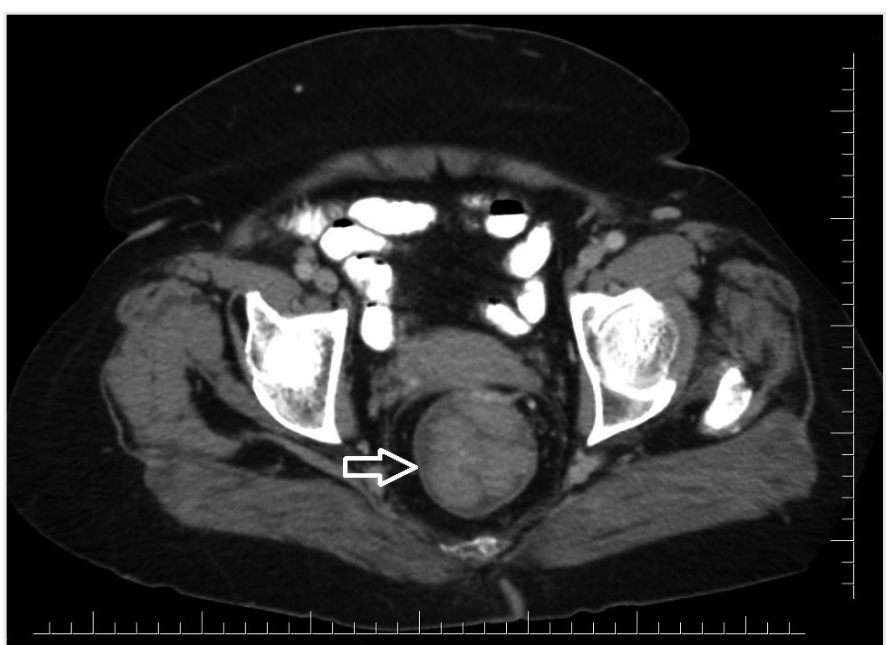

Figure 1. Arrow points the multilobular mass

dermatomyositis and diabetes (7). Our patient also had diabetes. As it is demonstrated in our case, the definitive treatment of these patient should be surgical, despite the presence of constellation of medical disorders (5). In the literature, endoscopic submucosal dissection has been reported to be feasible and useful for MWS treatment (8). In another study, it was reported that the symptoms of MWS may be reduced 48 hours after the start of indomethacin therapy (9). Transabdominal laparoscopic procedures are the most described methods in the treatment of MWS. Additionally, transanal minimally invasive surgery, has been reported as an alternative surgical approach (10).

\section{Conclusion}

Our case could be representing a mild form of MWS. Surgery should be undertaken in such cases, as there is high risk of malignancy and intractable nature of the electrolyte disorder.

Informed Consent: Informed consent was obtained from the patient.

Peer-review: Internally peer-reviewed.
Author Contributions: Concept - S.E., B.C.Y.; Design - S.Ö., D.T.; Supervision - B.C.Y., B.D.Y.; Data Collection and/or Processing - S.Ö., D.T.; Analysis and/or Interpretation - S.Ö., D.T., M.T.; Literature Search - S.E., B.D.Y.; Writing Manuscript - S.E., B.D.Y., M.T.; Critical Review - B.C.Y., M.T.

Conflict of Interest: No conflict of interest was declared by the authors.

Financial Disclosure: The authors declared that this study received no financial support.

\section{References}

1. Babior BM. Villous adenoma of the colon: Study of a patient with severe fluid and electrolyte disturbances. Am J Med 1966; 41: 615-21.

2. Mckittrick Jr, Mueller S, Starr A. Villous adenoma of the colon associated with severe hypopotassemia. AMA Arch Surg 1956; 73: 995-8.

3. Older J, Older P, Colker J, Brown R. Secretory villous adenomas that cause depletion syndrome. Arch Intern Med 1999; 159: 879-80.

4. Targarona EM, Hernandez PM, Balague C, Martinez C, Hernández J, Pulido D, et al. McKittrick-Wheelock syndrome treated by laparoscopy: report of 3 cases. Surg Laparosc Endosc Percutan Tech 2008; 18: 536-8.

5. Watari J, Sakurai J, Morita T, Yamasaki T, Okugawa T, Toyoshima F, et al. A case of Cronkhite-Canada syndrome complicated by McKittrick-Wheelock syndrome associated with advanced villous adenocarcinoma. Gastrointest Endosc 2011; 73: 624-6.

6. Wakeman CJ. Giant villous adenoma presenting as McKittrick-Wheelock syndrome and pseudo-obstruction. Med J Aust 2010; 192: 225-7.

7. Popescu A, Orban-Schiopu A, Becheanu G, Diculescu M. McKittrick-Wheelock syndromea rare cause of acute renal failure. Rom J Gastroenterol 2005; 14: 63-6.

8. Ohara Y, Toyonaga T, Watanabe D, Hoshi N, Adachi S, Yoshizaki T, et al. Electrolyte depletion syndrome (McKittrick-Wheelock syndrome) successfully treated by endoscopic submucosal dissection. Clin J Gastroenterol 2015; 8: $280-4$.

9. Kagan MD, Schmidt K, Sangha G. Indomethacin therapy effective in a patient with depletion syndrome from secretory villous adenoma. BMJ Case Rep 2017; 2017. pii: bcr2016217211.

10. van der Pool AEM, de Graaf EJR, Vermaas M, Barendse RM, Doornebosch PG. McKittrick Wheelock Syndrome Treated by Transanal Minimally Invasive Surgery: A Single-Center Experience and Review of the Literature. J Laparoendosc Adv Surg Tech A 2018; 28: 204-8. 